\title{
Personality: Blessing or Curse? The Entrepreneur's Path from Personal to Leadership Competencies
}

\author{
Michael Forster ${ }^{1}$, Philipp Parrer ${ }^{2}$, Nina Maria Wöss ${ }^{3}$ \\ 1Johnstraße 13/15, 1150 Wien, Austria, michael-forster@outlook.com \\ ${ }^{2}$ Welthandelsplatz 1, 1020 Wien, Austria, philipp.parrer@gmail.com \\ ${ }^{3}$ Spengergasse 37-39, 1050 Wien, Austria, woess@ @utlook.com mailto:h0751685@wu.ac.at
}

\begin{abstract}
This paper is based on a study which investigates the relevance of management competencies in Austrian organizations, focusing on start-ups. The study as well as the existing literature confirms that personal competencies such as ambition, selfconfidence or assertiveness are perceived as more important by start-ups than by established companies. However, further results of the paper show that especially leadership competencies play a major role in developing a growing start-up whereas personal competencies fade into the background and can even have a negative impact on turnover growth. In general, the paper discusses special characteristics of competence classes for start-ups and examines differences and similarities in comparison to established companies. As it has already been indicated, the evidence leads to different and surprising considerations for entrepreneurs and growing start-ups.
\end{abstract}

Key words: Classes of competencies, entrepreneurship, start-up

\section{Introduction}

Start-ups are operating in a difficult organizational environment which differs from the one established companies act in. In the course of the evolution of a start-up its managers have to adapt to changing circumstances. Among other factors flexibility, individual competencies, innovation capacity and networking play important roles regarding the success of an enterprise (Anderson, 1992: U.1.1; Hoang and Antoncic, 2003:173; Pearson, 1972: 116). The dynamic environment of start-ups can necessitate a development from an internal towards an external orientation (Zhang et al., 2006:304+). In general, the evolution of start-ups and the concomitant challenges can be explained on the basis of several stage and development models (e.g. Greiner, 1998: 56; Kazanjian and Drazin, 1990: 137+; Phelps, 2007: 13; Mount et al., 1993: $118+$ ).

Those models illustrate the strong connection between the development of a company and change management processes. Due to a lack of long-term strategies within startups, short-term and reactive change processes occur more frequently than in established companies (Ates and Bititci,
2011: 5614), which has a negative effect on the companies' success (Smith, 1998:867+). In its evolution a start-up has to face numerous change processes. However, this aspect is just one of many distinctive features which can be observed. Various theories focusing on the development of companies (e.g. Greiner, 1998; Phelps, 2007) in terms of change management (e.g. Kotter, 1997; Lewin, 1943; Pietschmann, 2008) and competence classes (e.g. Mühlbacher, 2007; Erpenbeck and von Rosenstiel, 2003) may help to understand and master those issues.

This paper analyzes special attributes as well as challenges of start-ups on the basis of the competence classes according to Mühlbacher (2007:131+): Methodological, leadership, social-communicative, self-dispositive, personal competencies. The paper aims to point out distinctions as well as characteristic features regarding the competence classes mentioned above by comparing start-ups and established companies in Austria.

Accordingly, the following research question needs to be dealt with: To what extent does the perception of competence classes between start-ups and established companies differ?

Received: $24^{\text {th }}$ August 2013; revised: $17^{\text {th }}$ September 2013; accepted: $26^{\text {th }}$ September 2013 


\section{Entrepreneurs and start-ups}

Small businesses are companies, where managers can act independently and are also often the founders who provide the necessary funds. Differences can normally be seen quantitatively, i.e. such companies differ according to the number of employees, turnover and total assets. Those small businesses usually operate in one key market and are, as well as mediumsized businesses, vital not only for the European but also for the global economy (Europäische Kommission, 2006: 5+; OECD, 2005:16+; Scott and Bruce, 1987:45+; WKO, 2012:1). In this context start-ups are usually integrated in the category of small businesses.

SME's and especially start-up's are often mentioned in the context of and related to the terms "foundation research" and "entrepreneurship", which are not clearly defined in theory. The characteristics of founders and their behavior, the motivation of founders (Corsten, 2002:7) as well as the risk and uncertainty aspect, which was defined by Cantillon (1755), are important aspects in this respect (Mugler and Fink, 2007:12+). Entrepreneurial visions and activities are major factors of this aspect (Brandl and Bullinger, 2007:52), and so are product- as well as market-innovations (Miller, 1983:771). Because of market exploitation (Franke, 2006:368) or emerging uncertainties, especially technological uncertainties (Littler and Pearson, $1972: 111+$ ), new opportunities can arise, which lead to incremental but also fundamental change. Thus, managers and founders have to be aware of and deal with those changes.

One major research field in the context of entrepreneurship is the network-based research. Social interactions and cooperation as well as the communication structure of entrepreneurs are of research interest (Bögenhold, 2007:36+). Therefore, social capital and networks are critical aspects for success. However, all resources but also all parties involved are partially determined and influenced by the basic structure of a particular company and its environment (Mücke and Rami, 2007: 139+). Nevertheless, a central role as well as great power is attributed to the entrepreneur.

Another important research field takes a close look at the strategies for SME's and start-ups, which are essential not only for the success but also for the survival of any organization (Cressy, 2006: 174; Romanelli, 1989: 381+). A high degree of agreement concerning objectives serves as a necessary thread running through the organizational development (Hueber, 2011: 70+). For start-ups as well as for established companies the definition of a vision and a mission as well as of objectives is a critical element of the strategy process (Kraus, 2006: 39). This process has to be seen as long-lasting and nonlinear (Fueglistaller et al., 2012: 178). Moreover, this development is not separated from the ensuing implementation process and has to be controlled permanently. In addition to commonly known strategic frameworks like Porter (1985), Ansoff (1965) or Mintzberg (1995), it should be mentioned that newly formulated concepts which have a strong appeal, such as the Business-Model Canvas by Osterwalder and Pigneur (2010) as well as the Long-Tail concept by Anderson (2007), are becoming more and more popular.

\section{Classes of competencies}

The concept of competence is defined differently throughout the existing literature. Moreover, the term has to be ana- lysed within the respective specific context (Hager, 1995:150; Erpenbeck and von Rosenstiel, 2003: XVIII+). North et al. (2013: 43), for example, define competence as the ability to act appropriately in specific situations, but this is just one of many definitions. A similar issue exists with regard to applied categories. Generally, distinctions are sometimes ambiguous, measurements are hard to make and comparability is not always guaranteed (Mühlbacher, 2007:130). One significant example is "leadership". Many different definitions have been published throughout history and in science different attributes are associated with the term (Barrow, 1977:231; Gupta, 1984:404; Bücker and Poutsma, 2010:830; Gosling et al., 2012:XVII)

Based on the concept of Erpenbeck and von Rosenstiel (2003a:XVII+), Mühlbacher (2007: 13) provides a classification of competencies which combines these concepts with Bourdieus' theory of society. As a result, methodological, leadership, social-communicative, self-dispositive and personal competencies are defined and separated from each other. In order to define the distinctions between the different theorybased competence-classes, Mühlbacher (2007:129+) provides competence-lists for each class separately. As a matter of fact, these lists can be extended.

In the following, the authors of this paper attempt to show the challenges for start-ups according to the competenceclass-framework.

\section{Methodological competencies}

This category contains different instruments for analytical thinking. It stands to reason that procedures for proceeding factual issues (Mühlbacher, 2007:134), where specific know-how, instrumental knowledge and capabilities are used creatively, are included (Erpenbeck and von Rosenstiel, 2003a: XXIV). Examples of these competencies are analytical / crosslinked / visionary thinking, change-management, strategic-management or market- \& industry-know-how (Mühlbacher, 2007:134+). Successful start-ups quantify and define objectives and guidelines clearly (Smith, 1998:867+). An early-stage strategic focus and a proper overall planning of the product-market combination have a positive impact on the growth rate. Moreover, the chosen strategy should be longlasting and should not be changed (Feeser and Willard, 1990: 95). However, Ates and Bitici (2011: 5624) show that many start-ups focus primarily on short-term and reactive changeprocesses. Thus, long-term and strategic planning is not respected appropriately. It is quite obvious that many organizational aspects like the strategic- and change-management, which belong to the methodological competencies, are underdeveloped in start-ups, especially at an early-stage, and have to be developed gradually. According to development-models (e.g. Phelps, 2007; Mount, 1993), which do not include a specific sequence of development stages, and also according to stage-models (e.g. Dodge and Robbins, 1992; Greiner, 1998; Kazanjian, 1988; Rutherford et al., 2003; Steinmetz, 1969; Scott and Bruce, 1987) this statement has been confirmed. Management tasks have to be delegated progressively and founders have to focus on managing aspects and not on questions of execution. Increasing growth leads to more organizational complexity and new organizational requirements arise 
steadily. As a result, change occurs and has to be dealt with appropriately (Mount et al., 1993: 119+). Phelps (2007: 13) points out that also the formal structure, which can be added to the methodological competencies (Mühlbacher 2007: 135), receives more attention as the organization is growing. So far the discussion shows that there is a tendency that, generally, methodological competencies receive less attention from early-stage start-ups than other competencies. In the wake of organizational growth this competence class becomes more and more important. It should be mentioned that this does not mean that methodological competencies are not critical success-factors. However, short-term reactive processes enjoy more attention than long-term strategic planning. This leads to hypothesis 1: Methodological competencies are perceived as less important by start-ups than by established companies.

\section{Leadership competencies}

Barrow (1977: 232) defines leadership as "the behavioral process of influencing individuals or groups towards set goals". This category contains instruments such as motivation, teamwork management (Goleman et al., 2002: 57), or human resources development (Chung-Herrera et al., 2003: 23; Mühlbacher, 2007: 144+). Characteristics and special issues of leadership in start-ups have been treated in the entrepreneurship-literature for ten years (Cogliser and Brigham, 2004: 771; D'Intino et al., 2007: 105; Hmieleski and Ensley, 2007: 865; Mugler and Fink, 2007: 11).Thus, many research papers deal with various issues of this competence class. In the course of an early start-up phase, standard business processes and the organizational structure are not defined. Therefore, founders, in comparison to managers of established companies, do not have fixed structures and reliable processes for leading the organization (Ensley et al., 2006: 258+). Thus, founders have to develop and implement such structures and processes. This means that they have to convey their vision to their team and inspire them (Baum et al., 1998: 43+; Cogliser and Brigham, 2004: 773). Moreover, objectives have to be agreed upon and human resource should be managed properly (Williamson, 2000: 27+). Another important aspect, especially for founding-teams, is that one founder has to act as "leadentrepreneur" and has to be responsible for leading not only the company but also the founding-team (Ensley et al., 2000: $72+$ ). Also stage and development models which describe the development of young companies address the leadership-issue (e.g. Greiner, 1998; Kazanjian and Drazin, 1990; Phelps et al., 2007). Greiner (1998: 59) describes a leadership-crisis as a phenomenon that arises after an early start-up stage. As a result, new management tasks demand a formalization of processes and the management itself has to be professionalized. Generally, also the management structure has to be developed. Thus, start-up members are confronted with flat hierarchies and little structures (Kazanjian and Drazin, 1990: 140+). An internal orientation, for example, which concentrates on product development, could be the result and the start-up has to learn to focus on external factors (Zhang et al., 2006: 308). A restructuring process triggered off by new overall conditions and initiated through an internal crisis after the first start-upstage is also discussed by Scott and Bruce (1987: 49+). One characteristic feature of this development is that the human resource management, which is also a leadership competency according to Mühlbacher (2007: 145), becomes more important. Also Phelps (2007: 8+) and Heneman et al. (2000: 18) emphasize this development. In conclusion, it seems that start-ups pay less attention to leadership competencies. Consequently, hypothesis 2 states: Leadership competencies are perceived as less important by start-ups than by established companies.

\section{Social-communicative competencies}

Social-communicative competencies describe behaviors as well as social interactions and contain, according to Erpenbeck (2010: 23), for example communicational-skills, cooperation-skills, flexibility or relationship-management. In addition, Mühlbacher (2007: 141+) adds moderation and conflict-management to this category. Leadership competencies are not included and are put into a category of its own (Mühlbacher, 2007: 82). Social-communicative competencies, according to Mühlbacher (2007: 142), have a high value for start-ups. Through an established communication network it is possible to reveal important market information but also better contract conditions. Lobbying (Peng, 2006: 32+) and networking (Hoang and Antoncic, 2003: 173; Arenius and Clercq, 2005: 260+; Brüderl and Preisendörfer, 1998: 220+) can also be of great interest for this purpose. Thus, internal and external communications have a significant value for entrepreneurs (Wang and $\mathrm{Wu}, 2012$ : 713). Furthermore, these social-communicative soft skills become increasingly important (Schmude, 2002: 248+). It seems to be obvious that social-communicative competencies play a key role for entrepreneurs in developing a start-up. In addition, Mueller et al. (2012: 1008) state that a central role for entrepreneurs is exchanging information and opinions. Wang and $\mathrm{Wu}$ (2012: 713) describe the importance of another social-competence, the ability to work in a team. Commitment (Wang and $\mathrm{Wu}$, 2012: 713) and trust (Wu et al., 2009: 353) have to be encouraged to gain competitive advantages. Based on the above discussion, it can be concluded that social-communicative competencies, according to Mühlbacher (2007: 82), have a high value for start-ups. Therefore, hypothesis 3 states: Socialcommunicative competencies are perceived as more important by start-ups than by established companies.

\section{Self-dispositive competencies}

Self-dispositive competencies describe skills which influence the self-management of an individual. The development of particular skills is based on conveyed values (Mühlbacher, 2007: 82+). Flexibility, time-management, stress tolerance, innovation capabilities or entrepreneurial thinking are relevant examples in this respect (Chung-Herrera et al., 2003: 20; Mühlbacher, 2007: 131). Generally, innovation capabilities and creativity as well as opportunity recognition are important factors for start-ups that do not only determine the market entry but also their whole development (Peng, 2006: 30+). If a start-up enters a new market, the product has to be adapted to external conditions which determine the environment of the market. Start-ups and entrepreneurs are trying to exploit opportunities within the market and consequently start-up businesses involve change processes (Franke, 2006: 368). 
These processes often imply market-product innovations which lead to changes of the status quo (Hauschildt, 2004: $3+)$. Self-dispositive competencies play a major role for the above discussed developments and processes. Greiner (1998: 58+) but also Kazanjian and Drazin (1990: 140+) describe that self-dispositive competencies like innovation capabilities, creativity, inventiveness or flexibility are significant factors regarding the organizational development, especially during an early start-up stage. Moreover, Littler and Pearson (1972: 116) argue that flexibility is essential for innovation processes and, additionally, Anderson (1992: U.1.1) describes flexibility and also individual skills and teamwork as central factors which are necessary for the success of a start-up. This discussion shows that self-dispositive competencies, according to Mühlbacher (2007: 131), like creativity, innovation capabilities and also flexibility play an important role, especially in an early start-up stage. Thus, hypothesis 4 can be derived as follows: Self-planning competencies are perceived as more important by start-ups than by established companies.

\section{Personal competencies}

This category contains personality characteristics which are stable over time. Examples are ambition, self-confidence or assertiveness (Mühlbacher, 2007: 146+). Beside sociodemographic factors, personal factors determine the character of an entrepreneur (Preisendörfer, 2002: 46). However, there is no specific characteristic feature that defines a successful entrepreneur. Although the person itself is a relevant and important factor, external influences like legal, cultural or political conditions have to be considered to analyze the success of a formation of a company, which is a complex socioeconomic and technical phenomenon (Jacobsen, 2006: 227+). Nonetheless, personality-tests like the NEO-FFI, according to Allport and Odbert (1936: 171+), help to understand specific characteristics of entrepreneurs and founders. On the one hand Tett et al. (1991: 732+) show that openness to new experiences and social compatibility have the highest correlation with efficient working behavior, on the other hand Salgado (1998: $282+$ ) describes that conscientiousness and emotional stability are most relevant for the working behavior. Furthermore, Barrick et al. (2001: 21+) postulate that conscientiousness and emotional stability have the highest validity for all criteria and types of professions. Managers have the highest development score as far as extraversion is concerned. In general, many publications show that special characteristics are very important for entrepreneurs and founders. For example willingness to take risk and pro-activity, which are also important for an aggressive competitive behavior (Lumpkin and Dess, 2001: $148+$ ), are prominent characteristics of successful founders (Preisendörfer, 2002: 46). Another example is that founders with a focus on growth attach more value to the character of a new employee or a partner than to the compatibility between abilities and job requirements (Heneman et al., 2000: 18). This focus can be partially described because the integration of a new member into the existing organizational culture has a significant value for founders. To conclude, there is a tendency that personal competencies are perceived as being more important for start-ups than for established companies: Thus, hypothesis 5 can be derived as follows: Personal competencies are perceived as more important by start-ups than by established companies.

\section{Methods}

The hypotheses mentioned above have been addressed through a quantitative study design. The questionnaire is based on seven closed questions. Five questions are focusing on the above mentioned classes of competencies, which are rated on a 6-point Likert scale. If one competence class has been rated higher than four, the respondents were asked to name the most important competency in this field. Furthermore, the proportional changes of human resources, turnover and profit within the last year have been evaluated.

The data were collected from 226 Austrian managers. 27 of the surveyed organizations are start-ups. Table 1 gives an overview of the represented industries.

\section{Results}

The empirical investigation starts with a descriptive analysis of the data. After building subsamples of start-ups and established companies, a Wilcoxon/Mann-Whitney test, ranking

Table 1: Industries distribution

\begin{tabular}{|c|c|c|c|c|}
\hline Industries & Total & Percent & Start-ups & Percent \\
\hline Consumer Goods & 41 & 18.1 & 5 & 15.4 \\
\hline Investment Goods & 3 & 1.3 & 0 & \\
\hline Communication / Information Technology & 29 & 12.8 & 13 & 50 \\
\hline Pharmaceutical Industry/ Chemistry & 6 & 2.7 & 0 & \\
\hline Consulting & 33 & 14.6 & 0 & \\
\hline Banks / Insurance / Financial Services & 37 & 16.4 & 2 & 7.7 \\
\hline Commercial Industry & 18 & 8.0 & 1 & 3.8 \\
\hline Others & 59 & 26.1 & 6 & 23.1 \\
\hline Total & 226 & 100.0 & 27 & 100.0 \\
\hline
\end{tabular}


order correlations as well as t-tests have been performed to gain insight into the characteristics of the subsamples. To address the companies' performance, regressions have been performed to predict revenue growth through competence classes. Based on the outcome of this regression analysis, a model optimization has been performed to further increase the explained variance.

A comparison between both subsamples of start-ups and established companies shows that the respondents of start-ups are significantly younger and encompass less management experience in years $(\mathrm{p}<0.05)$. Beyond that, the data in total show a high correlation between age and management experience (Pearson's r=0.84).

The multiple answer items of tasks evaluated by the respondents have been analyzed through a contingency table (Table 2).

The task mentioned most of the time throughout the total sample is marketing/sales as this task has been mentioned by

Table 2: Contingency table

\begin{tabular}{|c|c|c|c|c|c|c|}
\hline & & established companies & start-ups & total & Chi-Square & Sig. \\
\hline \multirow{3}{*}{$\begin{array}{l}\text { Marketing/ } \\
\text { sales }\end{array}$} & quantity & 85 & 18 & 103 & \multirow[t]{3}{*}{5.5} & \multirow[t]{3}{*}{0.19} \\
\hline & \% subsample & $42.70 \%$ & $66.70 \%$ & & & \\
\hline & $\%$ total & $37.60 \%$ & $8.00 \%$ & $45.60 \%$ & & \\
\hline \multirow[t]{3}{*}{ Production } & quantity & 9 & 7 & 16 & \multirow[t]{3}{*}{16.56} & \multirow[t]{3}{*}{0.0} \\
\hline & $\%$ subsample & $4.50 \%$ & $25.90 \%$ & & & \\
\hline & $\%$ total & $4.00 \%$ & $3.10 \%$ & $7.10 \%$ & & \\
\hline \multirow{3}{*}{$\begin{array}{l}\text { Procurement/ } \\
\text { logistics }\end{array}$} & quantity & 19 & 8 & 27 & \multirow[t]{3}{*}{9.11} & \multirow[t]{3}{*}{0.003} \\
\hline & $\%$ subsample & $9.50 \%$ & $29.60 \%$ & & & \\
\hline & $\%$ total & $8.40 \%$ & $3.50 \%$ & $11.90 \%$ & & \\
\hline \multirow{3}{*}{$\begin{array}{l}\text { Human } \\
\text { resources }\end{array}$} & quantity & 53 & 12 & 65 & \multirow[t]{3}{*}{3.68} & \multirow[t]{3}{*}{0.05} \\
\hline & $\%$ subsample & $26.60 \%$ & $44.40 \%$ & & & \\
\hline & $\%$ total & $23.50 \%$ & $5.30 \%$ & $28.80 \%$ & & \\
\hline \multirow[t]{3}{*}{ Organization } & quantity & 36 & 19 & 55 & \multirow[t]{3}{*}{35.289} & \multirow[t]{3}{*}{0.0} \\
\hline & $\%$ subsample & $18.10 \%$ & $70.40 \%$ & & & \\
\hline & $\%$ total & $15.90 \%$ & $8.40 \%$ & $24.30 \%$ & & \\
\hline \multirow[t]{3}{*}{ IT } & quantity & 14 & 12 & 26 & \multirow[t]{3}{*}{32.68} & \multirow[t]{3}{*}{0.0} \\
\hline & $\%$ subsample & $7.00 \%$ & $44.40 \%$ & & & \\
\hline & $\%$ total & $6.20 \%$ & $5.30 \%$ & $11.50 \%$ & & \\
\hline \multirow{3}{*}{$\begin{array}{l}\text { Finance/ } \\
\text { accounting/ } \\
\text { controlling }\end{array}$} & quantity & 39 & 15 & 54 & \multirow[t]{3}{*}{16.9} & \multirow[t]{3}{*}{0.0} \\
\hline & \% subsample & $19.60 \%$ & $55.60 \%$ & & & \\
\hline & $\%$ total & $17.30 \%$ & $6.60 \%$ & $23.90 \%$ & & \\
\hline \multirow{3}{*}{$\begin{array}{l}\text { Research \& } \\
\text { development }\end{array}$} & quantity & 8 & 11 & 19 & \multirow[t]{3}{*}{41.63} & \multirow[t]{3}{*}{0.0} \\
\hline & \% subsample & $4.00 \%$ & $40.70 \%$ & & & \\
\hline & $\%$ total & $3.50 \%$ & $4.90 \%$ & $8.40 \%$ & & \\
\hline \multirow{3}{*}{$\begin{array}{l}\text { Project } \\
\text { management }\end{array}$} & quantity & 39 & 18 & 57 & \multirow[t]{3}{*}{27.93} & \multirow[t]{3}{*}{0.0} \\
\hline & $\%$ subsample & $19.60 \%$ & $66.70 \%$ & & & \\
\hline & $\%$ total & $17.30 \%$ & $8.00 \%$ & $25.20 \%$ & & \\
\hline \multirow[t]{3}{*}{ Other } & quantity & 26 & 0 & 26 & \multirow[t]{3}{*}{3.99} & 0.046 \\
\hline & \% subsample & $13.10 \%$ & $0.00 \%$ & & & \\
\hline & $\%$ total & $11.50 \%$ & $0.00 \%$ & $11.50 \%$ & & \\
\hline quantity & & 199 & 27 & 226 & & \\
\hline$\%$ applied to t & & $88.10 \%$ & $11.90 \%$ & $100.00 \%$ & & \\
\hline
\end{tabular}


45.6 percent of all respondents. Concerning the subsample of start-ups, organization has been most frequently chosen with 70.4 percent followed by marketing/sales and project management with 66.7 percent each. Concerning established companies, marketing/sales with 42.7 percent has been the top choice followed by human resources with 26.6 percent.

The contingency table gives another impression of the differences between the work behavior of established companies and start-ups. While respondents of start-ups selected on average 4.4 tasks, the choice of established companies averaged at 1.6 tasks. This indicates that respondents of start-ups are confronted with a broader variety of tasks than respondents of established companies. Furthermore, the chi-square test shows that the frequencies observed differ significantly from the frequencies expected for all tasks except human resources.

Before investigating the differences of each competence class between both subsamples separately, a Wilcoxon/MannWhitney test has been performed in order to identify if the respondents' behavior of those two groups reflect an overall difference among all competence classes. This nonparametric test has been performed in order to identify the difference through ranking and, subsequently, its distribution of rank sums. As a result, no significant differences in the overall rating behavior have been found.

Surprisingly, there is a strong difference between the relevance of each individual competence class between start-ups and established companies. It seems that those competence classes that are ranked high in the subsample of established companies are found to be not that relevant in the subsample of start-ups and vice versa. The correlation between the ranking of established companies and start-ups concerning the relevance of the competence classes is distinctively negative (Spearman's $\rho=-0.5$ ).

Start-ups rated the methodological competencies with the highest relevance (average $=5.19$ ). Leadership competencies have been evaluated as the least important competence-class with an average score of 4.63. Established companies, however, found that the social-communicative competencies have the highest relevance with an average score of 4.93. The lowest relevance related to the self-dispositive competencies with an average score of 4.55 .

Table 3: Ranking order

\begin{tabular}{|c|c|c|}
\hline & Start-ups & established companies \\
\hline Methodological competencies & 1 & 3 \\
\hline Leadership competencies & 5 & 2 \\
\hline Social-communicative competencies & 4 & 1 \\
\hline Self-dispositive competencies & 3 & 5 \\
\hline Personal competencies & 2 & 4 \\
\hline
\end{tabular}

Note: $1=$ Highest value

Table 4 shows the results of the t-statistics in detail.

\begin{tabular}{|c|c|c|c|c|c|c|}
\hline \multicolumn{7}{|c|}{ Table 4: Independent Samples Test } \\
\hline & & $\mathbf{F}$ & Sig. & $\mathbf{t}$ & df & Sig. (2-tailed) \\
\hline \multirow{2}{*}{$\mathrm{mc}$} & Equal variances assumed & 1.064 & .303 & -3.051 & 224 & .003 \\
\hline & Equal variances not assumed & & & -3.365 & 35.774 & .002 \\
\hline \multirow[b]{2}{*}{$\operatorname{scc}$} & Equal variances assumed & .003 & .957 & .696 & 224 & .487 \\
\hline & Equal variances not assumed & & & .710 & 33.877 & .483 \\
\hline \multirow{2}{*}{ lc } & Equal variances assumed & 4.682 & .032 & .276 & 224 & .782 \\
\hline & Equal variances not assumed & & & .208 & 29.393 & .837 \\
\hline \multirow{2}{*}{$\mathrm{sdc}$} & Equal variances assumed & .175 & .676 & -1.968 & 224 & .050 \\
\hline & Equal variances not assumed & & & -1.879 & 32.558 & .069 \\
\hline \multirow{2}{*}{ pc } & Equal variances assumed & .027 & .871 & -2.504 & 224 & .013 \\
\hline & Equal variances not assumed & & & -2.316 & 32.021 & .027 \\
\hline
\end{tabular}


Concerning the leadership and social-communicative competencies, the t-test has not shown any significant differences between start-ups and established companies. Therefore, $\mathrm{H} 2$ and $\mathrm{H} 3$ cannot be supported.

Concerning methodological, self-dispositive and personal competencies, the t-test has shown significant differences between start-ups and established competencies. The relevance of those three competence-classes is significantly higher for start-ups than for established companies. As a result, $\mathrm{H} 1$ has not been confirmed, whereas $\mathrm{H} 4$ and $\mathrm{H} 5$ have been confirmed.

The following chapter examines the quality of competence classes to predict corporate success. Data about turnover and profit have been collected in the survey. However, as most start-ups do not have a focus on profit as they are in an early organizational stage, the majority of 23 respondents have a profit growth of 0 percent. Concerning turnover growth, the survey data reflect a more scattered response with an average score of 0.56 and a standard deviation of 1.05 . Therefore, regressions have been performed on the annual turnover growth. Besides, one respondent has been eliminated with a stated turnover growth of 500 percent.

Competence classes as a predictor for turnover growth

A linear regression has been performed that encompasses the influence of all competence classes. The underlying mathematical model is the least square method to estimate its parameters in the sense that the residues $\varepsilon_{i}$ are preferably small. The following equation of the regression analysis shows the dependent variable (turnover) as a function of methodological competences (mc), social-communicative competencies (scc), leadership competencies (lc), self-dispositive competencies (sdc) and personal competencies (pc).

turnover $_{i}=b_{0}+b_{1} \cdot m c+b_{2} \cdot s c c+b_{3} \cdot l c+b_{4} \cdot s d c+b_{5} \cdot p c+\varepsilon_{i}$

The adjusted coefficient of determination has a value of 0.214 , which indicates that 21.4 percent of the variance of turnover growth can be explained by the model. Consequently, 78.6 percent of the variance cannot be explained by the model because they underlie an influence outside the predicting model parameters.

The f-test of this model is not significant $(p=0.078)$, which states that the f-test returns a value that is not high enough to ensure that the explained variance from this model is significantly different from the variance explained from the prediction based on the average of turnover growth.

The t-tests of the explicit regression coefficients show that the personal competence class is the only coefficient that differs significantly from $0(\mathrm{p}<0.05)$. This fact reflects the influences through the competence classes. For example, methodological competencies have a beta of 0.002 , which means that a rise of this coefficient has almost no impact on the result of revenue.

Table 5: Regression coefficients

Model Summary

\begin{tabular}{|l|c|c|c|}
\hline $\mathbf{R}$ & R Square & Adjusted R Square & Std. Error of the Estimate \\
\hline $.609 \mathrm{a}$ & .371 & .214 & .50166 \\
\hline
\end{tabular}

a. Predictors: (Constant), mc, scc, lc, sdc, pc

ANOVA $^{\mathrm{a}}$

\begin{tabular}{|l|c|c|c|c|c|}
\hline & Sum of Squares & df & Mean Square & F & Sig. \\
\hline Regression & 2.968 & 5 & .594 & 2.359 & $.078^{\mathrm{b}}$ \\
\hline Residual & 5.033 & 20 & .252 & & \\
\hline Total & 8.002 & 25 & & & \\
\hline
\end{tabular}

a. Dependent Variable: turnover

b. Predictors: (Constant), mc, scc, lc, sdc, pc

\section{Coefficients $^{\mathrm{a}}$}

\begin{tabular}{|l|c|c|c|c|c|}
\hline \multirow{2}{*}{} & \multicolumn{2}{|c|}{ Unstandardized Coefficients } & Standardized Coefficients & \multirow{2}{*}{ Sig. } \\
\cline { 2 - 5 } & B & Std. Error & Beta & .709 & .486 \\
\hline (Constant) & .767 & 1.082 & & .011 & .991 \\
\hline $\mathrm{mc}$ & .002 & .157 & .002 & -.338 & .739 \\
\hline $\mathrm{scc}$ & -.049 & .145 & -.068 & 1.863 & .077 \\
\hline $\mathrm{lc}$ & .281 & .151 & .472 & 1.205 & .242 \\
\hline $\mathrm{sdc}$ & .169 & .140 & .262 & -3.168 & .005 \\
\hline $\mathrm{pc}$ & -.464 & .147 & -.715 & & -32 \\
\hline
\end{tabular}

a. Dependent Variable: turnover 
In conclusion, the category of personal competencies is the only significant regression parameter and has a negative impact on turnover growth. All other competence classes have a less influential impact on the outcome.

\section{Model optimization}

The previous regression of all competence classes has shown that some parameters do not resolve relevant impact on turnover growth. To gain further improvements of the regression model's prediction quality, a model optimization has been performed in order to determine relevant model parameters. Through stepwise inclusion, only those parameters have been included into the model that enhance the adjusted $R^{2}$. Compared to the $R^{2}$, the adjusted $R^{2}$ considers the increase of the degrees of freedom. Therefore, the inclusion of a model parameter can lower the adjusted $R^{2}$ if the variable leads to a loss of predictive power of the regression model.

The result of the optimized model is based on only three competence classes, namely leadership, self-dispositive and personal competencies. All other variables (social-communi- cative and methodological competencies) have not fulfilled the requirements to enter the model. The model explains almost a third of the spread (adjusted $R^{2}=0.281$ ) and the f-test is significant $(\mathrm{p}<0.05)$.

The model building method is forward stepwise using the adjusted $R^{2}$ criterion. A checkmark means the effect is in the model at this step.

The analysis shows that leadership and personal competencies differ significantly from 0 . In detail, leadership competencies have a significant positive impact on turnover growth, whereas personal competencies influence turnover growth negatively.

\section{Discussion}

This paper analyzes differences and special issues of competence classes according to Mühlbacher (2007) comparing start-ups with established companies. Hypothesis 1 describes that methodological competencies are perceived as less impor-

Table 6: Regression coefficients

\begin{tabular}{|l|l|c|c|c|}
\hline \multirow{2}{*}{\multicolumn{2}{|c|}{ Adjusted R Square }} & \multicolumn{3}{|c|}{ Step } \\
\cline { 3 - 5 } \multicolumn{2}{|c|}{} & $\mathbf{1}$ & $\mathbf{2}$ & $\mathbf{3}$ \\
\cline { 3 - 5 } & $\mathrm{pc}$ & .162 & .262 & .281 \\
\hline \multirow{3}{*}{ Effect } & $\mathrm{pc}$ & $\checkmark$ & $\checkmark$ & $\checkmark$ \\
\cline { 2 - 5 } & $\mathrm{cc}$ & & $\checkmark$ & $\checkmark$ \\
\cline { 2 - 5 } & $\mathrm{sdc}$ & & & $\checkmark$ \\
\hline
\end{tabular}

Model Summary

\begin{tabular}{|l|c|c|c|}
\hline R & R Square & Adjusted R Square & Std. Error of the Estimate \\
\hline $.606 \mathrm{a}$ & .367 & .281 & .47980 \\
\hline
\end{tabular}

a. Predictors: (Constant), pc, lc, sdc

ANOVA $^{\mathrm{a}}$

\begin{tabular}{|l|c|c|c|c|c|}
\hline Model & Sum of Squares & df & Mean Square & F & Sig. \\
\hline Regression & 2.937 & 3 & .979 & 4.253 & $.016^{\mathrm{b}}$ \\
\hline Residual & 5.065 & 22 & .230 & & \\
\hline Total & 8.002 & 25 & & & \\
\hline
\end{tabular}

a. Dependent Variable: turnover

b. Predictors: (Constant), pc, lc, sdc

\section{Coefficients $^{\mathrm{a}}$}

\begin{tabular}{|l|c|c|c|c|c|}
\hline \multirow{2}{*}{ Model } & \multicolumn{2}{|c|}{ Unstandardized Coefficients } & Standardized Coefficients & \multirow{2}{*}{ Sig. } \\
\cline { 2 - 6 } & $\mathbf{B}$ & Std. Error & Beta & .802 & .431 \\
\hline (Constant) & .615 & .767 & .128 & 1.270 & .217 \\
\hline sdc & .163 & .137 & -.704 & -3.346 & .003 \\
\hline pc & -.457 & .112 & .443 & 2.363 & .027 \\
\hline lc & .264 & & & & \\
\hline
\end{tabular}

a. Dependent Variable: turnover 
tant by start-ups than by established companies. This hypothesis has been derived from existing literature which shows that start-ups focus on short-term and reactive change processes whereas long-term and strategic planning is not respected appropriately (Ates and Bitici, 2011: 5624). Development models (e.g. Phelps, 2007; Mount, 1993) but also stage models (e.g. Dodge and Robbins, 1992; Greiner, 1998; Kazanjian, 1988; Rutherford et al., 2003; Steinmetz, 1969; Scott and Bruce, 1987) support this conclusion. However, the data show that the opposite is the case. A reason for this result could be that the start-ups within this sample are moderately successful and 50 percent of them have already received seed or venture capital or funding from the public sector. This may also indicate that strategic elements have already been developed. Furthermore, venture capitalists and capital providers consult start-ups after their investments and contribute to the development of important methodological elements. Hypothesis 2 states that leadership competencies are perceived as less important by start-ups. The data disprove hypothesis 2 and show that no significant difference can be found. Again, this result could be influenced by the success of the included start-ups. Ensley et al. (2006: 258+) mention that leadership structures have to be implemented, according to Baum et al. (1998: 43+) the corporate vision has to be clearly communicated to all employees and Williamson (2000: 27+) points out that common objectives have to be agreed upon. Thus, it can be concluded that the start-ups within the sample might have already implemented the elements mentioned above and therefore, hypothesis 2 cannot be supported. Regarding hypothesis 3 , which states that social-communicative competencies are perceived as more important by start-ups, the analysis shows that no significant differences exist and therefore the hypothesis cannot be supported. The literature suggests that elements like networking (Hoang and Antoncic, 2003: 173; Arenius and Clercq, 2005: 260+; Brüderl and Preisendörfer, 1998: 220+) or lobbying (Peng, 2006: 32+) are essential tools for start-ups. That does not mean that those tools are not helpful for established companies as well. Hypotheses 4 and 5 state that self-dispositive and personal competencies are perceived as more important by start-ups than by established companies. Both hypotheses can be supported by the data. Thus, the approach derived from the literature can be confirmed. Self-dispositive competencies like innovation capabilities, creativity, inventiveness or flexibility (e.g. Greiner, 1998: 58+; Kazanjian and Drazin, 1990: 140+) play a major role for startups, especially during an early-stage development. Moreover, the focus on personal competencies like willingness to take risk, pro-activity and an aggressive competitive behavior (Lumpkin and Dess, 2001: 148+) and the importance of a particular personality profile of a new member of an organization (Heneman et al., 2000: 18) can be confirmed. To sum up, the analysis shows that differences regarding the perception of competence classes between start-ups and established companies do actually exist. Differences and special issues arise due to extraordinary conditions start-ups usually have to face. Apart from the results regarding the defined hypotheses, further observations through regression analyses and model optimization have been generated.
The analysis shows that leadership as well as personal competencies have a significant impact on turnover growth. As mentioned above, hypothesis 5 states that personal competencies are perceived as more important by start-ups than by established companies and this perception has been supported by the data. This approach can also be supported by existing literature. On the contrary, the regression shows that personal competencies have a negative impact on turnover growth of start-ups whereas leadership competencies have a positive impact. This result indicates that leadership competencies can help to grow turnover and entrepreneurs have to implement leadership structures earlier than they would consider them to be relevant. That means that given structures where the focus is on the entrepreneurs' personal competencies have to be replaced before they are not suitable for new challenges a growing organization has to face. A new organizational and leadership structure is needed to delegate business tasks and support entrepreneurs. The result of this study indicates that a start-up with a strong focus on the personality of a particular entrepreneur, in different stages of its development, is likely to experience a leadership crisis which can be prevented by changing the focus and by implementing a new organizational and leadership structure before problems arise. Nevertheless, it should be emphasized that without the personal competencies of an entrepreneur, no start-up could be established and built up successfully. After all and to conclude, the path of a successful entrepreneur is likely to lead from personal to leadership competencies.

\section{Literature}

Allport, G. W. \& Odbert, H. S. (1936). Trait-names: A psycho-lexical study. Psychological Monographs: General and Applied, 47(1), 171-220

Anderson, C. (1992). Successful Start-up Management, American Association of Cost Engineers. Transactions of the American Association of Cost Engineers, 2(1), U.1.1-U.1.7

Anderson, C. (2007). The long tail. München: Hanser.

Ansoff, H.I. (1965). Checklist for Competitive and Competence Profiles, Corporate Strategy. New York: McGraw-Hill.

Arenius, P. \& Clercq, D. (2005). A Network-based Approach on Opportunity Recognition. Small Business Economics, 24(3), 249-265, http://dx.doi.org/10.1007/s11187-005-1988-6

Ates, A. \& Bitici, U. (2011). Change process: a key enabler for building resilient SMEs. International Journal of Production Research, 49(18), 5601-5618, http://dx.doi.org/10.1080/00207 543.2011.563825

Barrick, M. R., Mount, M. K. \& Judge, T. A. (2001). Personality and performance at the beginning of the new millennium: what do we know and where do we go next?. International Journal of Selection and Assessment, 9(1-2), 9-30, http:// dx.doi.org/10.1111/1468-2389.00160

Barrow, J. C. (1977). The variables of leadership: A review and conceptual framework. Academy of Management Review, 2(2), 231-251, http://dx.doi.org/10.5465/AMR.1977.4409046

Baum, J. R., Locke, E. A. \& Kirkpatrick, S. A. (1998). A longitudinal study of the relation of vision and vision communication to venture growth in entrepreneurial firms. Journal of Applied Psychology, 83(1), 43-54, http://dx.doi.org/10.1037/00219010.83.1.43 
Bögenhold, D. (2007). Entrepreneurship im Kontext: Zur Wichtigkeit sozialwissenschaftlicher Aspekte der Gründungsforschung. In Fink, M., Kraus, S. \& Almer-Jarz, D. A. (Eds.), Sozialwissenschaftliche Aspekte des Gründungsmanagements (pp. 28-51). Stuttgart: IBIDEM.

Brandl, J. \& Bullinger, B. (2007). Entrepreneurship als Institution: Gesellschaftlicher Kontext und individuelle Perspektive. In Fink, M., Kraus, S. \& Almer-Jarz, D. A. (Eds.), Sozialwissenschaftliche Aspekte des Gründungsmanagements (pp.52-68). Stuttgart: IBIDEM.

Brüderl, J. \& Preisendörfer, P. (1998). Network Support and the Sucess of Newly Founded Business. Small Business Economics, 10(3), 213-225, http://dx.doi.org/10.1023/A:1007997102930

Bücker, J. \& Poutsma, E. (2010). Global management competencies: a theoretical foundation. Journal of Managerial Psychology, 25(8), 829-844, http://dx.doi.org/10.1108/02683941011089116

Cantillon, R. (1755). Essai sur la nature de commerce en general. Paris. (English: Higgs, H. (1931) For the Royal Economic Society. London: Macmillan.)

Chung-Herrera, B. G., Enz, C. A. \& Lankau, M. J. (2003). A Competencies Model Grooming Future Hospitality Leaders. Cornell Hotel and Restaurant Administration Quarterly, 44(3), 17-25, http://dx.doi.org/10.1177/001088040304400302

Cogliser, C. C. \& Brigham, K. H. (2004). The intersection of leadership and entrepreneurship: Mutual lessons to be learned. Leadership Quarterly, 15(6), 771-799, http://dx.doi. org/10.1016/j.leaqua.2004.09.004

Corsten, H. (2002). Determinanten der Gründungsentscheidung - Ein empirischer Befund. In Corsten, H. (Ed.), Dimensionen der Unternehmensgründung - Erfolgsaspekte der Selbständigkeit (pp. 3-41). Berlin: Erich Schmidt.

Cressy, R. (2006). Determinants of small firm survival and growth. In Casson, M. \& Yeung, B., Basu, A. \& Wadeson, N. (Eds.), The Oxford Handbook of Entrepreneurship (pp. 161-193). OxfordNew York: Oxford University Press.

D'Intino, R. S., Goldsby, M. G., Houghton, J. D. \& Neck, C. P. (2007). Self-leadership: A process for entrepreneurial success. Journal of Leadership \& Organizational Studies, 13(4), 105120, http://dx.doi.org/10.1177/10717919070130040101

Dodge, H.R. \& Robbins, J.E. (1992). An empirical investigation of the organizational life-cycle model for small business development and survival. Journal of Small Business Development, 30(1), 27-37.

Ensley, M. D., Carland, J. W. \& Carland, J. C. (2000). Investigating the existence of the lead entrepreneur. Journal of Small Business Management, 38(4), 59-77.

Ensley, M. D., Pearce, C. L. \& Hmieleski, K. M. (2006). The moderating effect of environmental dynamism on the relationship between entrepreneur leadership behavior and new venture performance. Journal of Business Venturing, 21(2), 243-263, http:// dx.doi.org/10.1016/j.jbusvent.2005.04.006

Erpenbeck, J. (2010). Kompetenzen erkennen, bilanzieren und entwickeln. In Schneider, K. (Ed.), Kompetenzbilanzierung \& Orientierung Arbeitsuchender - Ein Leitfaden zur Förderung der Handlungsbefähigung, 5.Auflage (pp. 21-26). Stuttgart: Klaus Schneider.

Erpenbeck, J. \& von Rosenstiel, L. (2003). Vorbemerkung zur zweiten Auflage. In Erpenbeck, J. \& von Rosenstiel, L. (Eds.), Handbuch Kompetenzmessung, Erkennen, verstehen und bewerten von Kompetenzen in der betrieblichen, pädagogischen und psychologischen Praxis. 2. Auflage (XI - XV). Stuttgart: Schäffer Poeschl.

Erpenbeck, J. \& von Rosenstiel, L. (2003a). Einführung. In Erpenbeck, J. \& von Rosenstiel, L. (Eds.), Handbuch Kompetenzmessung, Erkennen, verstehen und bewerten von Kompetenzen in der betrieblichen, pädagogischen und psychologischen Praxis. 2. Auflage (pp. XVII - XLVI). Stuttgart: Schäffer Poeschl.

Europäische Kommission (2006). Die neue KMU Definition. Refrieved May 5, 2013 from http://ec.europa.eu/enterprise/policies/sme/files/sme definition/sme user guide de.pdf

Feeser, H.R. \& Willard, G.E. (1990). Founding Strategy and Performance: A Comparison of High and Low Growth High Tech Firms. Strategic Management Journal, 11(2), 87-98, http:// dx.doi.org/10.1002/smj.4250110202

Franke, N. (2006). Entrepreneurship. In Köhler, R. \& Küpper, H-U. \& Pfingsten, A. (Eds.), Handbuch der Betriebswirtschaft. 6.Auflage (pp. 367-374). Stuttgart: Schäfer Poeschel.

Fueglistaller, U. \& Christoph, M. \& Volery, T. (2012). Entrepreneurship, Modelle - Umsetzung - Perspektiven, Mit Fallbeispielen aus Deutschland, Österreich und der Schweiz. 3. Auflage. Wiesbaden: Springer-Gabler.

Goleman, D. \& Boyatzis, R. \& McKee, A. (2002). Emotionale Führung. München: Econ.

Gosling, J. \& Sutherland, I. \& Jones, S. \& Dijstra, J. (2012). Leadership: Key Concept. London: Sage.

Greiner, L. (1998). Evolution and Revolution as Organizations Grow. Harvard Business Review, May-June, 55-67.

Gupta, A. K. (1984). Contingency linkages between strategy and general manager characteristics: A conceptual examination. Academy of Management Review, 9(3), 399-412, http://dx.doi. org/10.5465/AMR.1984.4279658

Hager, P. (1995). Competency Standards - a Help or a Hindrance? An Australian Perspective. The Vocational Aspect of Education, 47(2), 141-151, http://dx.doi.org/10.1080/0305787950470203

Hauschildt, J. (2004). Innovationsmanagement. 3. überarbeitete Version. München: Vahlen.

Heneman, R. L., Tansky, J. W. \& Camp, S. M. (2000). Human Resource Management Practices in Small and Medium-Sized Enterprises: Unanswered Questions and Future Research Perspectives. Entrepreneurship: Theory \& Practice, 25(1), 11-26.

Hmieleski, K. M. \& Ensley, M. D. (2007). A contextual examination of new venture performance: entrepreneur leadership behavior, top management team heterogeneity, and environmental dynamism. Journal of Organizational Behavior, 28(7), 865-889, http://dx.doi.org/10.1002/job.479

Hoang, H. \& Antoncic, B. (2003). Network-based research in entrepreneurship: A Critical review. Journal of Business Venturing, 18(2), 165-187, http://dx.doi.org/10.1016/S08839026(02)00081-2

Hueber, R. (2011). Ein-Personen-Unternehmen - Ein Leitfaden zur erfolgreichen Gründung, Steuerung und Führung. Graz-Wien: dbv.

Jacobsen,L.K.(2006).ErfolgsfaktorenbeiderUnternehmensgründung. Wiesbaden: Gabler.

Kazanjian, R.K. (1988). Relation of Dominant Problems to Stages of Growth in Technology-Based New Ventures. The Academy of Management Journal, 31(2), 257-279, http://dx.doi. org $/ 10.2307 / 256548$

Kazanjian, R.K. \& Drazin, R. (1990). A Stage-Contingent Model of Design and Growth for Technology based New Ventures. Journal of Business Venturing, 5(3), 137-150, http://dx.doi. org/10.1016/0883-9026(90)90028-R

Kotter, J. P. (1997). Chaos, Wandel, Führung - Leading Change. Düsseldorf: Econ.

Kraus, S. (2006). Strategische Planung und Erfolg junger Unternehmer. Wiesbaden: GWV Fachverlage.

Littler, D. \& Pearson, A. (1972). Uncertainty and technological Innovation. Management Decision, 10(2), 111-116, http:// dx.doi.org/10.1108/eb000988 
Lumpkin, G.T. \& Dess, G.G. (2001). Linking two dimensions of entrepreneurial orientation to firm performance: The moderating role of environment and industry life cycle. Journal of Business Venturing, 16(5), 429-451, http://dx.doi.org/10.1016/S08839026(00)00048-3

Miller, D. (1983). The Correlates of Entrepreneurship in Three Types of Firms. Management Science, 29(7), 770-791, http://dx.doi. org/10.1287/mnsc.29.7.770

Mintzberg, H. (1995). Die strategische Planung: Aufstieg, Niedergang und Neubestimmung. München, Wien, London: Hanser.

Mount, J.J., Zinger, T. \& Forsyth, G.R. (1993). Organizing for Development in the Small Business. Long Range Planning, 26(4), 111-120, http://dx.doi.org/10.1016/0024-6301(93)90083$\mathrm{R}$

Mücke, T. \& Rami, U. (2007). Soziales Kapital und Nutzung von Netzwerkstrukturen durch Unternehmerinnen - Eine empirische Analyse. In Fink, M. \& Kraus, S. \& Almer-Jarz, D. A. (Eds.), Sozialwissenschaftliche Aspekte des Gründungsmanagements (pp. 139-162) Stuttgart: IBIDEM.

Mugler,J.\&Fink, M.(2007). Sind250 JahreEntrepreneurshipforschung schon genug?. In Fink, M. \& Kraus, S. \& Almer-Jarz, D. A. (Eds.), Sozialwissenschaftliche Aspekte des Gründungsmanagements (pp. 10-27). Stuttgart: IBIDEM.

Mueller, S., Thierry, V. \& Von Siemens, B. (2012). What Do Entrepreneurs Actually Do? An Observational Study of Entrepreneurs' Everyday Behavior in the Start-up and Growth Stages. Entrepreneurship Theory and Practice, 36(1), 995-1017, http://dx.doi.org/10.1111/j.1540-6520.2012.00538.x

Mühlbacher, J. (2007). Kompetenzmanagement als Grundlage strategischer Wettbewerbsvorteile. Wien: Linde.

North, K., Reinhardt, K. \& Sieber-Suter, B. (2013). Kompetenzmanagement in der Praxis - Mitarbeiterkompetenzen systematisch identifizieren, nutzen und entwickeln. 2. Auflage. Wiesbaden: Springer Gabler.

OECD (2005). SME and Entrepreneurship Outlook 2005. Retrieved May 5,2013 from http://www.oecd-ilibrary.org/the-role-ofsmes-and-entrepreneurship-in-oecd-economies_514trxm3xv8n. pdf? contentType $=/ \mathrm{ns} /$ Chapter $\&$ ite $\mathrm{mI} d=/$ content $/$ chapter/9789264009257-3-en\&containerItemId=/content/ book/9789264009257-en\&accessItemIds=\&mimeType=applic ation/pdf 6

Osterwalder, A. \& Pigneur, Y. (2010). Business Model Generation - Ein Handbuch für Visionäre, Spielveränderer und Herausforderer. Frankfurt-New Work: Campus.

Peng, M. W. (2006). How Entrepreneurs Create Wealth in Transition Economies. In Cooper, A. \& Alvarez, S. \& Carrera, A. \& Mesquita, L. \& Vassolo, R. (Eds.), Entrepreneurial Strategies: New Technologies in Emerging Markets (pp. 26-46). Malden: Wiley-Blackwell.

Phelps, R., Adams, R. \& Bessant, J. (2007). Life cycles of growing organizations: A review with implications for knowledge and learning. International Journal of Management Review, 9(1), 1-30, http://dx.doi.org/10.1111/j.1468-2370.2007.00200.x

Pietschmann, H. (2008). Change Management und Dialektik. In Mühlbacher, J., Scheer, P. J., Schmidt, A. \& von Rosenstiel, L. (Eds.), Management Development (pp. 243-352). Wien: Linde.

Porter, M.E. (1985). Competitive Advantage. New York: Free Press.

Preisendörfer, P. (2002). Erfolgsfaktoren von Unternehmensgründungen - Theorieansätze und empirische Ergebnisse. In Corsten, H. (Ed.), Dimensionen der Unternehmensgründung - Erfolgsaspekte der Selbständigkeit (pp. 45-70). Berlin: Erich Schmidt.
Romanelli, E. (1989). Environments and Strategies of Organization Start-up: Effects on Early Survival. Administrative Science Quarterly, 34(3), 369-387, http://dx.doi. org/10.2307\%2F 2393149

Rutherford, M.W., Buller, P.F. \& Mcmullen, P.R. (2003). Human resource management problems over the life cycle of small to medium sized firms. Human Resource Management, 42(1), 321335, http://dx.doi.org/10.1002/hrm.10093

Salgado, J. F. (1998). Big Five personality dimensions and job performance in army and civil occupations: A European perspective. Human Performance, 11(2-3), 271-288, http://dx.doi.org/10.10 $80 / 08959285.1998 .9668034$

Schmude, J. (2002). Standortwahl und Netzwerke von Unternehmensgründern. In Dowling, M \& Drumm, H. J. (Eds.), Gründungsmanagement (pp. 247-260). Berlin-Heidelberg: Springer.

Scott, M. \& Bruce, R. (1987). Five Stages of Growth in Small Business. Long Range Planning, 20(3), 45-52, http://dx.doi. org/10.1016/0024-6301(87)90071-9

Smith, J.A. (1998). Strategies for Start-ups, Long Range Planning. 31(6), 857-872, http://dx.doi.org/10.1016/S00246301(98)80022-8

Steinmetz, L.L (1969). Critical stages of small business growth: When they occur and how to survive them, Business Horizons. 12(1), 29-36, http://dx.doi.org/10.1016/0007-6813(69)90107-4

Tett, R.P., Jackson, D.N. \& Rothstein, M. (1991). Personality measures as predictors of job performance: a meta-analytic review. Personnel Psychology, 44(4), 703-742, http://dx.doi. org/10.1111/j.1744-6570.1991.tb00696.x

Wang, C.-J \& Wu, L.-Y. (2012). Team member commitments and start-up competitiveness. Journal of Business Research, 65(5), 708-715, http://dx.doi.org/10.1016/j.jbusres.2011.04.004

Williamson, I. O. (2000). Employer legitimacy and recruitment success in small businesses. Entrepreneurship Theory and Practice, 25(1), 27-42

Zhang, M., Macpherson, A., \& Jones, O. (2006). Conceptualizing the Learning Process in SMEs: Improving Innovation through External Orientation. International Small Business Journal, 24(3), 299-323, http://dx.doi.org/10.1177/0266242606063434

Michael Forster achieved his bachelor's degree in Business Administration in 2011 and in 2013 his master's degree in Management at WU (Vienna University of Economics and Business). Currently he is employed by a forwarding agency as management assistant.

Philipp Parrer received his bachelor's degree in Business Administration in 2011 and his master's degree in Management in 2013 at WU (Vienna University of Economics and Business). He is currently working in the field of product marketing.

Nina Maria Wöss graduated in International Business Administration in 2011 and in 2013 received her master's degree in Management at WU (Vienna University of Economics and Business). She is currently employed as a research associate at an Austrian business angel fund. 